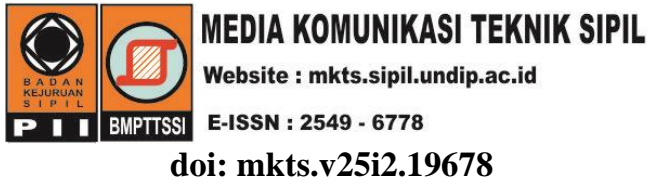

\title{
Analisis Undang Undang yang Mengatur Jasa Konstruksi Indonesia Terhadap Pengguna dan Penyedia Jasa Konstruksi
}

\author{
"Andi Bayu Putra1, Hendrik Sulistio² \\ ${ }^{1}$ Fakultas Teknik, Teknik Sipil, Bina Nusantara University, Jakarta \\ ${ }^{2}$ Program Studi Teknik Sipil, Universitas Tarumanagara, Jakarta \\ *)andibayuputra@gmail.com
}

Received: 30 Juli 2018 Revised: 16 November 2011 Accepted: 11 Desember 2019

\begin{abstract}
Construction Services Law is a statutory regulation that is used to regulate all matters involving construction services, whereas in this study conducted in Jakarta, Indonesia, Law No. 18 of 1999 about Construction Services and Law No. 2 of 2017 about Construction Services. With changes in the Construction Services Law, there are differences in the form of revisions, additions, and reductions. These differences and changes are analyzed with the aim of developing a better Construction Services Law in the future. The method used in this research is a literature study method and questionnaire survey method. Questionnaire questions were formed based on literature studies from previous research and Construction Services Law discussed in this study. Data obtained from respondents were entered into the IBM SPSS Statistics 23 program and then conducted a validity test, reliability test, correlation test, and regression analysis. The analysis shows that there are several Construction Services Law's regulations which cannot be a good guide for construction service providers and users yet, due to: the provisions regarding building failures are not well explained, the general lack of provisions governing the selection of expert assessors, the lack of clarity governing labor standards construction work and unclear regulations regarding sanctions for parties involved in construction work.
\end{abstract}

Keywords: Construction service act, construction service user, construction service provider, construction services laws

\begin{abstract}
Abstrak
Undang - Undang Tentang Jasa Konstruksi (UUJK) adalah peraturan perundang - undangan yang dipakai untuk mengatur segala hal yang melibatkan jasa konstruksi, dimana pada penelitian ini yang dilakukan di Jakarta, Indonesia, dipakai Undang - Undang No. 18 Tahun 1999 Tentang Jasa Konstruksi (UUJK18/1999) dan Undang - Undang No. 2 Tahun 2017 Tentang Jasa Konstruksi (UUJK2/2017). Dengan perubahan UUJK, tentunya ada perbedaan - perbedaan berupa revisi, tambahan, dan pengurangan. Perbedaan dan perubahan ini dianalisis dengan tujuan untuk pengembangan UUJK yang lebih baik dimasa depan. Metode yang dipakai dalam penelitian ini adalah metode studi pustaka dan metode survei kuesioner. Pertanyaan kuesioner dibentuk berdasarkan studi pustaka dari penelitian terdahulu dan UUJK yang dibahas dalam penelitian ini. Data yang didapatkan dari responden dimasukkan kedalam program IBM SPSS Statistics 23, selanjutnya dilakukan uji validitas, uji reliabilitas, uji korelasi, analisis faktor, dan analisis regresi. Hasil analisis menunjukkan bahwa ada beberapa peraturan UUJK yang belum bisa menjadi panduan yang baik untuk penyedia dan pengguna jasa konstruksi yang dikarenakan oleh: ketetapan mengenai kegagalan bangunan tidak dijelaskan dengan baik, kurangnya ketetapan umum yang mengatur pemilihan penilai ahli, kurang jelasnya ketetapan yang mengatur standar tenaga kerja konstruksi dan kurang jelasnya peraturan mengenai sanksi untuk pihak - pihak yang terlibat dalam pekerjaan konstruksi.
\end{abstract}

Kata kunci : Undang-undang jasa konstruksi, pengguna jasa, penyedia jasa, ketetapan jasa konstruksi 


\section{Pendahuluan}

Berdasarkan Undang-Undang Nomor 12 Tahun 2011 tentang Pembentukan Peraturan Perundangundangan, yang dimaksud dengan undang-undang adalah peraturan perundang-undangan yang dibentuk oleh Dewan Perwakilan Rakyat (DPR) dengan persetujuan bersama presiden (Chandra, 2018; Undang - Undang Nomor 12 Tahun 2011). Peraturan hukum undang - undang yang dibahas dalam penelitian ini adalah Undang - Undang Nomor 18 Tahun 1999 tentang Jasa Konstruksi (selanjutnya UUJK 18/1999) dan Undang-Undang Nomor 2 Tahun 2017 tentang Jasa Konstruksi (selanjutnya UUJK2/2017). Perbedaan-perbedaan yang ditemukan diantara kedua peraturan ini yang menjadi dasar penelitian yang dilakukan.

Perbedaan yang disebabkan oleh perubahan ketetapan undang undang tentang jasa konstruksi akan diterima dengan sikap tertentu oleh pihakpihak yang bekerja di dunia konstruksi, bisa diterima dengan baik atau bisa diterima dengan kurang baik oleh penyedia jasa konstruksi maupun pengguna jasa konstruksi. Untuk melihat respon tersebut dengan jelas maka perlu dilakukan penelitian terhadap berbagai pihak yang bergerak di dunia konstruksi. Melalui hasil ini undangundang tentang jasa konstruksi bisa dikembangkan menjadi lebih baik dimasa depan.

Dengan berubahnya UUJK yang berlaku di Indonesia, akan ada perubahan-perubahan yang terjadi terhadap peraturan yang berlaku. Perubahan ini akan merubah bagaimana pengguna dan penyedia jasa konstruksi menjalankan kegiatan Jasa Konstruksi. Perubahan peraturan ini bisa membuat jalannya kegiatan Jasa Konstruksi lebih lancar atau lebih terhambat dikarenakan peraturan baru yang terlalu ambigu atau dikarenakan kekurangan-kekurangan lain. Dengan mengukur sikap pengguna dan penyedia jasa terhadap perubahan yang terjadi dan terhadap UUJK2/2017 maka bisa ditemukan peraturan mana saja yang masih membutuhkan pengembangan dan perbaikan untuk di masa depan. Melalui hasil penelitian, diharapkan undang-undang tentang jasa konstruksi bisa dikembangkan menjadi lebih baik dimasa depan.

Dengan perubahan hukum maka tentunya akan ada perubahan sosial dan perubahan budaya dari hal yang diatur hukum tersebut, dalam hal ini adalah hukum-hukum jasa konstruksi yang diatur di dalam UUJK. Maka dengan metode kuesioner, diupayakan untuk mengukur seberapa baik atau buruk hukum yang baru ditanggapi oleh tiap-tiap komponen jasa konstruksi, terutama pengguna dan penyedia jasa konstruksi. Dikatakan oleh Soerjono
(1981) dan Ridwan (2016), bahwa sebagai sarana untuk mengubah perlakuan tergantung proses pelembagaan dan bidang-bidang yang mau diubah. Dalam penelitian ini berarti pada bidang-bidang yang ingin diubah, yakni jalannya kegiatan jasa konstruksi di Indonesia. Dikatakan juga oleh Hasan (2011) bahwa tindakan hukum dikatakan efektif bila perilaku bergerak ke arah yang dikehendaki, ketika subjek patuh atau menurut.

Pada penelitian ini dengan metode kuesioner, mengukur seberapa besar baik UUJK dalam mengatur perilaku kegiatan jasa konstruksi berdasarkan sikap partisipan kegiatan jasa konstruksi (owner, kontraktor, konsultan, dan pihak terkait lainnya) terhadap UUJK yang berfungsi sebagai panduan. Dengan variabelvariabel bebas yang dibentuk melalui kombinasi antara penelitian terdahulu dan perubahanperubahan yang ditemukan diantara UUJK18/1999 dan UUJK2/2017. Hasil variabel bebas yang ditemukan dianalisis dengan hasil variabel terikat yang berupa pernyataan penyedia dan pengguna jasa terhadap kegunaan UUJK menjadi panduan bagi penyedia dan pengguna jasa konstruksi.

Batasan yang diambil adalah penelitian dibatasi kepada Undang-Undang Nomor 18 Tahun 1999 tentang Jasa Konstruksi dan Undang-Undang Nomor 2 Tahun 2017 tentang Jasa Konstruksi. Responden dan pakar yang digunakan adalah pihak-pihak yang bekerja di bidang teknik sipil atau bidang lain yang berhubungan dengan topik yang dibahas dengan pengalaman kerja minimal 4 tahun.

Tujuan dari penelitian ini adalah untuk mengetahui peraturan apa saja dari undang-undang jasa konstruksi yang saat ini berlaku, belum bisa dijadikan panduan yang baik atau perlu pengembangan, bagi pengguna jasa konstruksi dan penyedia jasa konstruksi.

\section{Metode}

Penelitian ini adalah melakukan studi literatur untuk mencari perbedaan diantara kedua UUJK yang ada, dan melalui penelitian-penelitian terdahulu yang telah dilakukan dibentuk variabel bebas dan variabel terikat.

Ridha (2017) mengatakan variabel bebas adalah variabel stimulus, prediktor. Variabel yang mempengaruhi atau menjadi sebab berubahnya variabel terikat. Variabel terikat yang juga disebut sebagai variabel output, konsekuen, adalah variabel yang dipengaruhi atau menjadi akibat. Metode yang dipakai adalah survei menggunakan penyebaran kuesioner, yaitu daftar pertanyaan 
tertulis yang ditujukan kepada responden (Endah, 2011). Jumlah responden ini adalah 60 orang, yaitu para individual yang sudah memiliki pengalaman \pm 4 tahun di bidang teknik sipil atau bidang lain yang berhubungan dengan topik penelitian. Sedangkan responden untuk wawancara adalah individualindividual dengan jenjang pengalaman lebih dari 15 tahun. Jawaban responden atas semua pertanyaan dalam kuesioner kemudian dicatat atau direkam.

Data yang dihasilkan dari survey dianalisis menggunakan program IBM SPSS Statistics 23. Software ini akan membantu perhitungan yang dilakukan agar memberi hasil yang akurat dan menghindari "human error". Uji dan analisis yang dilakukan oleh program ini adalah uji validitas, uji reliabilitas, uji korelasi, uji normalitas, uji multikolinearitas, dan analisis regresi.

Pada penelitian ini digunakan metode analisis regresi dikarenakan analisis regresi merupakan metode paling tepat untuk menemukan tujuan dari penelitian yang menggunakan metode kuesioner. Analisis regresi dipilih paling tepat sebagai metode analisis penelitian ini dikarenakan pada penelitian ini dicari hubungan fungsional antara variabel bebas dan terikat (Pratomo \& Astuti, 2015). Hasil dari analisis regresi akan memungkinkan untuk memprediksikan tanggapan responden terhadap variabel $\mathrm{Y}$ dan memperlihatkan variabel bebas mana saja yang memiliki pengaruh terbesar terhadap variabel $\mathrm{Y}$.

Berdasarkan analisis regresi menghasilkan rumus yang mampu memprediksi persepsi responden (variabel Y), sehingga bisa ditemukan variabel/ketentuan apa dari UUJK yang perlu diperbaiki. Metode analisis regresi berganda yang digunakan adalah analisis regresi stepwise, keputusan ini didasarkan oleh penelitian Pujilestari et al. (2017) yang mengatakan bahwa untuk analisis regresi linear berganda terbaik adalah stepwise dan best subset regression, dalam penelitian ini digunakan metode stepwise. Tahapan dan metode terakhir adalah menggunakan wawancara terstruktur terhadap hasil yang didapat dari hasil analisis, yang berguna untuk validasi serta menambah poin - poin yang diberikan oleh ahli yang diwawancara.

Sebelum dilakukan penyebaran kuesioner kepada 60 responden dilakukan dahulu pilot sample terhadap 15 responden untuk menguji validitas dan reliabilitas variabel kuesioner, dengan hasil uji reliabilitas menunjukkan katagori sangat baik (cronbach's alpha $>0,8$ ) dan mengeliminasi dua variabel bebas berdasarkan hasil uji validitas. Penelitian dilanjutkan dengan penyebaran kuesioner terhadap 60 responden. Kuesioner yang dipakai dalam penelitian menggunakan skala Likert dengan lima tingkat/ katagori yang umumnya digunakan (Maryuliana et al. 2016).

\section{Hasil dan Pembahasan}

Terdapat beberapa penelitian terdahulu yang membahas mengenai peraturan konstruksi dengan penyedia dan pengguna jasa konstruksi. Penelitian terdahulu yang digunakan sebagai acuan penelitian ini adalah penelitian mengenai potensi masalah yang menghambat keberlanjutan konstruksi pada aspek K3 berdasarkan UUJK2/2017 (Liyanto, 2017), penelitian mengenai analisis kegagalan bangunan dengan menggunakan UUJK18/1999 dan UUJK2/2017 (Ariadi, 2017), analisis faktor penyimpangan pada kontrak konstruksi oleh pengguna jasa (Kristanto, 2016), dan mengenai pelanggaran kewajiban pengguna jasa berdasarkan kontrak FIDIC dan AS4000-1997 (Widodo, 2015).

\section{Profil dan karakteristik responden}

Gambar 1 menunjukkan profil dan karakteristik responden. Responden-responden yang diminta untuk berpartisipasi minimal memiliki jenjang pekerjaan sebagai staff, dengan paling tinggi didapat adalah project manager dan procurement project manager.

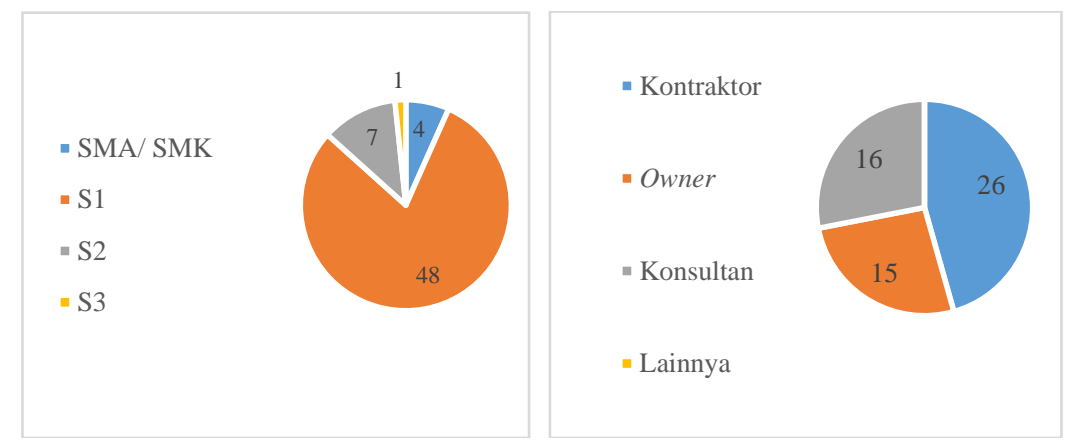

a. Pendidikan

b. Terakhir bidang pekerjaan

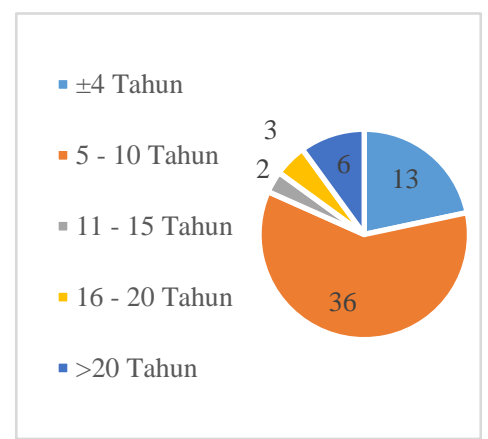

c. Pengalaman bekerja

Gambar 1. Jenjang pendidikan, bidang pekerjaan, dan pengalaman kerja responden 


\section{Perbedaan UUJK18/1999 dengan UUJK2/2017}

UUJK18/1999 memiliki 12 bab dengan 46 pasal, sedangkan UUJK2/2017 mempunyai 14 bab dengan 106 pasal, maka terdapat penambahan 2 bab, 60 pasal baru, dan perubahan sistematika. Perbedaan-perbedaan yang ditemukan bisa dijabarkan sebagai berikut:

1. Penambahan dan perubahan dalam UUJK2/2017, yaitu penambahan 2 Bab dan 60 Pasal baru, dan perubahan sistematika Undang - Undang Jasa Konstruksi, dengan UUJK18/1999 memiliki 12 Bab dengan 46 Pasal dan UUJK2/2017 mempunyai $14 \mathrm{Bab}$ dengan 106 Pasal.

2. Pada bab ketentuan umum terdapat beberapa penambahan pada UUJK2/2017 terhadap beberapa penjelasan terhadap maksud dan istilah yang dipakai di dalam Undang - Undang Jasa Konstruksi.

3. Penambahan ketetapan yang memberi pembahasan mengenai tanggung jawab dan kewenangan Pemerintah Pusat, Pemerintah Daerah Provinsi, dan Pemerintah Daerah Kabupaten di bidang Jasa Konstruksi.

4. Pada bagian bentuk dan klasifikasi usaha terdapat penambahan penjelasan mengenai klasifikasi jasa konstruksi pada UUJK2/2017, seperti kualifikasi bagi perseorangan, dan kualifikasi usaha bagi badan usaha yang terdiri atas kecil, menengah, dan besar, dengan penjelasan lainnya yang bisa dilihat pada halaman lampiran.

5. Penambahan bagian segmentasi pasar jasa konstruksi di dalam UUJK2/2017 pada Bab 4 Bagian Kedua Pasal $21-25$.

6. Pada UUJK2/2017 untuk bagian persyaratan usaha, keahlian dan keterampilan jasa konstruksi ditambahkan peraturan untuk badan usaha perseorangan.

7. UUJK2/2017 menjelaskan lebih dalam mengenai tanda usaha perseorangan dan izin usaha pada Bab 4 Pasal 27 - 29 dibanding UUJK18/1999 pada Bab 3 Pasal 10.

8. Sertifikat badan usaha dijelaskan lebih dalam pada UUJK2/2017 pada Bab 4 Pasal 30 dibanding UUJK18/1999 pada Bab 3 Pasal 9.

9. Bagian tanda daftar pengalaman dijelaskan lebih mendalam pada UUJK2/2017 Bab 4 Pasal 31 dibanding dengan UUJK18/1999 pada Bab 3 Pasal 10.
10. Penambahan ketetapan baru pada UUJK2/2017 untuk badan usaha jasa konstruksi asing dan usaha perseorangan jasa konstruksi asing pada Bab 4 Pasal 32 -35.

11. Bagian tanggung jawab profesional dijelaskan lebih baik di dalam UUJK18/1999 pada Bab 3 Pasal 11 dibanding dengan UUJK2/2017 pada Bab 4 Pasal 37.

12. Pada UUJK2/2017 ada penambahan ketetapan baru pada Bab 4 Pasal 37 yang menjelaskan mengenai pengembangan usaha berkelanjutan.

13. UUJK2/2017 menjelaskan mengenai pemilihan penyedia jasa konstruksi dengan lebih mendalam pada Bab 5 pasal 41 - 45 dibanding UUJK18/1999 pada Bab 4 Pasal 17.

14. Perihal kontrak kerja konstruksi baik UUJK18/1999 Pada Bab 4 Pasal 22 dan UUJK2/2017 pada Bab 5 Pasal 46 - 45 sudah menjelaskan dengan baik, tetapi pada UUJK2/2017 menjelaskan mengenai peraturan pembentukan kontrak kerja konstruksi dengan lebih baik.

15. UUJK2/2017 pada Bab 5 Pasal 52 - 54 menjelaskan mengenai penyedia dan sub penyedia jasa lebih mendalam dibanding UUJK18/1999 pada Bab 5 Pasal 24.

16. Penambahan ketetapan di dalam UUJK2/2017 mengenai pembiayaan jasa konstruksi pada Bab 5 Pasal 55 - 57, penyediaan bangunan pada Bab 5 Pasal 58, mengenai keamanan, keselamatan, kesehatan, dan keberlanjutan konstruksi pada Bab 6, perihal penilai ahli pada Bab 6 Pasal 61 - 64, jangka waktu dan pertanggung jawaban kegagalan bangunan pada Bab 6 Pasal 65 - 67, dan mengenai tenaga kerja konstruksi pada Bab 7.

17. Pada UUJK2/2017 tidak dijelaskan dengan mendalam mengenai peran masyarakat, tetapi pada UUJK18/1999 dijelaskan mengenai peran masyarakat pada Bab 7 .

18. Penambahan ketetapan di dalam UUJK2/2017 mengenai sistem informasi jasa konstruksi pada Bab 9 dan partisipasi masyarakat pada Bab 10.

19. Pada bagian sanksi, terdapat perbedaan judul diantara UUJK18/1999 dengan UUJK2/2017. Pada UUJK18/1999 tidak diatur pihak - pihak yang terlibat, tetapi diatur mengenai akibat, hukuman, dan denda sanksi, sedangkan pada UUJK2/2017 dijelaskan mengenai pihak pihak yang terlibat tetapi tidak menjelaskan tentang akibat hukuman, dan denda sanksi. 
Berdasarkan hasil analisis bisa disimpulkan bahwa, walau telah ada perubahan dan penambahan di dalam undang-undang tentang jasa konstruksi yang berlaku saat ini, hasil responden menunjukkan bahwa ketetapan UUJK belum mampu menjadi panduan yang baik.

\section{Kuesioner}

Pembentukan kuesioner didasarkan melalui penelitian terdahulu dan melalui studi pustaka. Kuesioner dibuat dengan mengadaptasi pertanyaan-pertanyaan yang ada di dalam penelitian terdahulu tersebut sebagai dasar pembentukan variabel bebas (variabel X). Variabel pertanyaan yang dibentuk berdasarkan adaptasi penelitian terdahulu dibentuk dengan melihat perbedaan ketetapan jasa konstruksi diantara UUJK18/1999 dengan UUJK2/2017. Variabelvariabel $\mathrm{X}$ bisa dilihat pada Tabel 1, dengan variabel terikat (variabel Y) adalah "undang undang jasa konstruksi belum memenuhi kriteria yang dibutuhkan sebagai panduan penyedia dan pengguna jasa konstruksi”.

Variabel Y dibentuk melalui adaptasi penelitian terdahulu dan berdasarkan tujuan dari penelitian ini.

Tabel 1. Variabel bebas

\begin{tabular}{|c|c|c|c|c|c|}
\hline \begin{tabular}{|l|l|} 
No \\
\end{tabular} & Variabel X & Sumber & No & Variabel X & Sumber \\
\hline $\mathrm{X} 1$ & $\begin{array}{l}\text { Kurangnya definisi dan } \\
\text { penjelasan mengenai } \\
\text { tanggung jawab dan } \\
\text { kewenangan pemerintah } \\
\text { pusat }\end{array}$ & $\begin{array}{l}\text { Ariadi (2017), } \\
\text { Liyanto (2017), } \\
\text { dan Widodo } \\
(2015)\end{array}$ & X11 & $\begin{array}{l}\text { Kurangnya ketetapan yang } \\
\text { menjelaskan tentang } \\
\text { Keselamatan, Kesehatan, } \\
\text { Keamanan (K3) dan } \\
\text { Keberlanjutan }\end{array}$ & $\begin{array}{l}\text { Ariadi (2017), } \\
\text { Liyanto (2017), } \\
\text { dan Widodo } \\
(2015)\end{array}$ \\
\hline $\mathrm{X} 2$ & $\begin{array}{l}\text { Kurang jelasnya ketetapan } \\
\text { yang menjelaskan } \\
\text { mengenai sifat, klasifikasi, } \\
\text { dan layanan usaha jasa } \\
\text { konstruksi }\end{array}$ & $\begin{array}{l}\text { Ariadi (2017), } \\
\text { Liyanto (2017), } \\
\text { dan Widodo } \\
(2015)\end{array}$ & $\mathrm{X} 12$ & $\begin{array}{l}\text { Ketetapan mengenai } \\
\text { kegagalan bangunan tidak } \\
\text { dijelaskan dengan baik }\end{array}$ & $\begin{array}{l}\text { Ariadi (2017), } \\
\text { Liyanto (2017), } \\
\text { dan Widodo } \\
(2015)\end{array}$ \\
\hline X3 & $\begin{array}{l}\text { Kurangnya penjelasan } \\
\text { mengenai segmentasi pasar } \\
\text { yang ada dalam peraturan } \\
\text { undang - undang }\end{array}$ & $\begin{array}{l}\text { Ariadi (2017), } \\
\text { Liyanto (2017), } \\
\text { dan Widodo } \\
(2015)\end{array}$ & $\mathrm{X} 13$ & $\begin{array}{l}\text { Kurangnya ketetapan yang } \\
\text { mengatur pemilihan Penilai } \\
\text { Ahli }\end{array}$ & $\begin{array}{l}\text { Ariadi (2017), } \\
\text { Liyanto (2017), } \\
\text { dan Widodo } \\
(2015)\end{array}$ \\
\hline $\mathrm{X} 4$ & $\begin{array}{l}\text { Kurangnya peraturan } \\
\text { mengenai usaha jasa } \\
\text { konstruksi perseorangan } \\
\text { dan badan usaha }\end{array}$ & $\begin{array}{l}\text { Ariadi (2017), } \\
\text { Liyanto (2017), } \\
\text { dan Widodo } \\
(2015)\end{array}$ & X14 & $\begin{array}{l}\text { Kurang jelasnya ketetapan } \\
\text { yang mengatur standar } \\
\text { Tenaga Kerja Konstruksi }\end{array}$ & $\begin{array}{l}\text { Ariadi (2017), } \\
\text { Liyanto (2017), } \\
\text { dan Widodo } \\
(2015)\end{array}$ \\
\hline X5 & $\begin{array}{l}\text { Kurangnya ketetapan yang } \\
\text { mengatur mengenai badan } \\
\text { usaha/ perseorangan jasa } \\
\text { konstruksi asing }\end{array}$ & $\begin{array}{l}\text { Ariadi (2017), } \\
\text { Liyanto (2017), } \\
\text { dan Widodo } \\
(2015)\end{array}$ & $\mathrm{X} 15$ & $\begin{array}{l}\text { Peran masyarakat di dalam } \\
\text { kegiatan konstruksi tidak } \\
\text { diatur dengan jelas }\end{array}$ & $\begin{array}{l}\text { Ariadi (2017), } \\
\text { Liyanto (2017), } \\
\text { dan Widodo } \\
(2015)\end{array}$ \\
\hline X6 & $\begin{array}{l}\text { Kurangnya penjelasan } \\
\text { dalam ketetapan mengenai } \\
\text { pengembangan usaha jasa } \\
\text { konstruksi }\end{array}$ & $\begin{array}{l}\text { Ariadi (2017), } \\
\text { Liyanto (2017), } \\
\text { dan Widodo } \\
(2015)\end{array}$ & X16 & $\begin{array}{l}\text { Pembinaan jasa konstruksi } \\
\text { tidak diatur dengan jelas dan } \\
\text { mendetail }\end{array}$ & $\begin{array}{l}\text { Ariadi (2017), } \\
\text { Liyanto (2017), } \\
\text { dan Widodo } \\
(2015)\end{array}$ \\
\hline $\mathrm{X} 7$ & $\begin{array}{l}\text { Kurang jelasnya ketetapan } \\
\text { yang membahas } \\
\text { pengembangan usaha } \\
\text { berkelanjutan }\end{array}$ & $\begin{array}{l}\text { Ariadi (2017), } \\
\text { Liyanto (2017), } \\
\text { dan Widodo } \\
(2015)\end{array}$ & $\mathrm{X} 17$ & $\begin{array}{l}\text { Kurang jelasnya peraturan } \\
\text { mengenai sistem informasi di } \\
\text { dalam jasa konstruksi }\end{array}$ & $\begin{array}{l}\text { Ariadi (2017), } \\
\text { Liyanto (2017), } \\
\text { dan Widodo } \\
\text { (2015) }\end{array}$ \\
\hline $\mathrm{X} 8$ & $\begin{array}{l}\text { Kurangnya ketetapan } \\
\text { dalam pengaturan } \\
\text { pemilihan penyedia jasa }\end{array}$ & $\begin{array}{l}\text { Ariadi (2017), } \\
\text { Liyanto (2017), } \\
\text { dan Widodo } \\
(2015)\end{array}$ & $\mathrm{X} 18$ & $\begin{array}{l}\text { Ketetapan mengenai } \\
\text { penyelesaian sengketa tidak } \\
\text { ditulis dengan jelas }\end{array}$ & $\begin{array}{l}\text { Ariadi (2017), } \\
\text { Liyanto (2017), } \\
\text { dan Widodo } \\
(2015)\end{array}$ \\
\hline X9 & $\begin{array}{l}\text { Kurangnya penjelasan } \\
\text { dalam ketetapan kontrak } \\
\text { kerja konstruksi dan } \\
\text { peraturannya }\end{array}$ & $\begin{array}{l}\text { Ariadi (2017), } \\
\text { Liyanto (2017), } \\
\text { dan Widodo } \\
(2015)\end{array}$ & X19 & $\begin{array}{l}\text { Kurang jelasnya peraturan } \\
\text { mengenai sanksi untuk pihak } \\
\text { - pihak yang terlibat dalam } \\
\text { pekerjaan konstruksi }\end{array}$ & $\begin{array}{l}\text { Ariadi (2017), } \\
\text { Liyanto (2017), } \\
\text { dan Widodo } \\
(2015)\end{array}$ \\
\hline X10 & $\begin{array}{l}\text { Kurangnya penjelasan } \\
\text { mengenai ketetapan } \\
\text { pembiayaan jasa } \\
\text { konstruksi }\end{array}$ & $\begin{array}{l}\text { Ariadi (2017), } \\
\text { Liyanto (2017), } \\
\text { dan Widodo } \\
(2015)\end{array}$ & $\mathrm{X} 20$ & $\begin{array}{l}\text { Peraturan mengenai denda } \\
\text { tidak dijelaskan dengan jelas } \\
\text { dan mendetail }\end{array}$ & $\begin{array}{l}\text { Ariadi (2017), } \\
\text { Liyanto (2017), } \\
\text { dan Widodo } \\
(2015)\end{array}$ \\
\hline
\end{tabular}

Sumber: Hasil adaptasi penelitian terdahulu, 2018 
Andi Bayu Putra, Hendrik Sulistio

Analisis Undang Undang ...

Tabel 2. Hasil regresi linier

\begin{tabular}{ccccc}
\hline Model & $\boldsymbol{R}$ & $\boldsymbol{R}$ square & Adjusted $\boldsymbol{R}$ square & Std. error of the estimate \\
\hline 1 & $0,313^{\mathrm{a}}$ & 0,098 & 0,082 & 0,90556 \\
2 & $0,408^{\mathrm{b}}$ & 0,167 & 0,137 & 0,87806 \\
\hline
\end{tabular}

Tabel 3. Hasil tes ANOVA

\begin{tabular}{llcccc}
\hline \multicolumn{1}{c}{ Model } & Sum of squares & df & Mean square & F & Sig. \\
\hline 1 & Regression & 5,163 & 1 & 5,163 & $0,015^{\mathrm{b}}$ \\
& Residual & 47,563 & 58 & 0,820 & \\
& Total & 52,726 & 59 & & \\
& Regression & 8,780 & 2 & 4,390 & 5,694 \\
& Residual & 43,946 & 57 & $0,006^{\mathrm{c}}$ & \\
& Total & 52,726 & 59 & & \\
& & &
\end{tabular}

Tabel 4. Koefisiena regresi linier

\begin{tabular}{ccccccc}
\hline \multirow{2}{*}{ Model } & \multicolumn{2}{c}{ Unstandardized coefficients } & $\begin{array}{c}\text { Standardized } \\
\text { coefficients }\end{array}$ & t & Sig. \\
\cline { 3 - 6 } & & $\mathbf{B}$ & Std. error & Beta & & \\
\hline \multirow{2}{*}{1} & (Constant) & 1,958 & 0,456 & & 4,297 & 0,000 \\
& $\mathrm{X} 13$ & 0,317 & 0,126 & 0,313 & 2,509 & 0,015 \\
\hline \multirow{2}{*}{2} & (Constant) & 1,183 & 0,569 & & 2,080 & 0,042 \\
& $\mathrm{X} 13$ & 0,277 & 0,124 & 0,274 & 2,241 & 0,029 \\
& $\mathrm{X} 19$ & 0,262 & 0,121 & 0,265 & 2,166 & 0,035 \\
\hline
\end{tabular}

Kuesioner yang dipakai, menggunakan skala Likert dengan lima tingkat/katagori yaitu; angka satu menunjukkan "sangat tidak setuju", angkat dua menunjukkan "tidak setuju", angkat tiga menunjukkan "netral", angka empat menunjukkan "setuju", dan angka lima menunjukkan "sangat setuju“ (Maryuliana et al. 2016).

\section{Hasil uji validitas}

Dalam penelitian ini digunakan rumus Spearman Brown untuk menghitung validitas dari survei dengan data skala ordinal dan dengan bantuan IBM SPSS 23 (Widodo, 2015). Validitas digunakan untuk menguji apakah alat ukur yang digunakan memang benar - benar mengukur benda yang ingin diukur (Widjaja \& Sandjaja 2013). Seluruh hasil uji validitas variabel kuesioner menunjukkan nilai diatas 0,214 yang merupakan batas nilai yang didapatkan melalui Upper Critial Values of Spearman's Rank Correlation Coefficient $R_{s}$. Widodo (2015) mengatakan bahwa nilai tersebut memutuskan variabel adalah valid atau tidak. Hasil ini menunjukkan bahwa alat ukur/kuesioner yang digunakan adalah valid dan mampu menjadi alat ukur bagi yang sesuatu yang akan diukur.

\section{Hasil uji reliabilitas}

Uji reliabilitas berguna untuk menetapkan apakah instrumen bisa digunakan lebih dari satu kali, hanya saja tidak boleh terhadap responden yang sama, dengan koefisien cronbach alpha menunjukkan reliabilitas suatu instrumen (Fanani et al. 2018). Uji pada penelitian ini menghasilkan nilai cronbach's alpha sebesar 0,888 dan berdasarkan rentang nilai reliabilitas, nilai ini dinyatakan memiliki reliabilitas dengan pengukuran sangat baik (Mahlangu \& Kruger, 2015). Ketika suatu konstruk memiliki nilai cronbach's alpha >0,6 konstruk tersebut sudah bisa dinyatakan reliabel (Ernawijaya, 2015).

\section{Hasil analisis korelasi}

Uji korelasi yang digunakan adalah korelasi Pearson untuk mengetahui hubungan antar variabel secara linier (Nugroho et al. 2014). Sebelum uji korelasi dilakukan, maka data ordinal yang didapatkan melalui data kuesioner perlu diubah ke dalam bentuk interval. Perubahan ini dilakukan dengan menggunakan metode yang dikenal sebagai method of successive interval, yang pada penelitian ini dilakukan dengan bantuan MS. Excel.

Berdasarkan hasil yang didapat, variabel terikat (variabel Y) memiliki korelasi yang cukup kuat dengan 4 variabel bebas (variabel $\mathrm{X}$ ) dengan signifikansi 0,05, yaitu: variabel X13 dengan nilai korelasi terbesar, yaitu 0,313; dengan X19 adalah variabel terbesar kedua dengan nilai 0,305 ; X14 dengan nilai 0,287 ; sedangkan X12 dengan nilai terkecil yaitu 0,275 . Variabel - variabel bebas dipilih berdasarkan tingkat signifikansinya yaitu 0,05 dan 0,01. Semakin kuat hubungan korelasinya maka semakin tinggi nilai korelasi Pearson yang 
dihasilkan, sedangkan semakin kuat hubungan korelasinya maka nilai signifikansinya akan semakin kecil.

\section{Hasil uji normalitas}

Salah satu sikap yang digunakan berkaitan dengan penerapan teorema limit pusat umumnya adalah distribusi sampling dari rata - rata sampel bisa mendekati distribusi normal bila ukuran sampel lebih dari 30 (Nurudin et al. 2014). Jumlah responden adalah 60, sehingga berdasarkan teorema limit pusat maka data adalah terdistribusi normal.

Untuk penelitian ini uji normalitas dengan program tetap dijalankan, dengan uji normalitas menggunakan metode kurtosis - skewness. Data dinilai terdistribusi normal bila di dalam kolom statistic dan ratio berada diantara 1,96 dan -1,96, dengan hasil uji menunjukkan bahwa data sudah terdistribusi normal (Ghasemi \& Zahediasl, 2012).

\section{Hasil analisis regresi}

Analisis dilanjutkan dengan analisis regresi linear berganda menggunakan metode stepwise, yang merupakan hubungan yang didapat dan dinyatakan dalam bentuk persamaan dimana persamaan menyatakan hubungan fungsional masing - masing variabel (Pratomo \& Astuti 2015). Analisis regresi adalah teknik statistik yang digunakan untuk mengestimasi hubungan antar variabel yang mempunyai relasi dengan jelas (Uyanik \& Guler, 2013).

Pada penelitian ini dilakukan analisis linear berganda karena menggunakan lebih dari satu variabel bebas (Haslinda \& Jamaluddin, 2016). Analisis dilakukan untuk mendapatkan model regresi linier dan menentukan variabel yang paling berpengaruh terhadap hasil analisis lain. Analisis ini dilakukan terhadap 4 variabel yang terpilih, dengan hasil analisis regresi linier bisa dilihat di bawah. Analisis regresi yang digunakan adalah metode stepwise, karena pemilihan model regresi linier berganda terbaik diantaranya adalah stepwise dan best subset regression (Pujilestari et al. 2017).

Tabel 2 di atas menunjukkan model yang paling sesuai menggambarkan hubungan antara variabel bebas dengan variabel terikat, yaitu model yang memiliki nilai $\mathrm{R}$ square terbesar, dalam hal ini adalah Model-2. Model ini menunjukkan bahwa hasil responden menunjukkan undang - undang jasa konstruksi belum memenuhi kriteria yang dibutuhkan sebagai panduan penyedia dan pengguna jasa konstruksi dipengaruhi sebanyak $16,7 \%$ oleh variabel X13 (kurangnya ketetapan yang mengatur pemilihan penilai ahli) dan X19 (kurang jelasnya peraturan mengenai sanksi untuk pihak-pihak yang terlibat dalam pekerjaan konstruksi).

Tabel 3 di atas menunjukkan hasil tes ANOVA yang menunjukkan untuk masing - masing model nilai $p$-value (kolom sig.) kurang dari 0,05 yang menunjukkan adanya signifikansi antara variabel bebas dengan variabel terikat, baik untuk model 1 atau Model-2. Nilai dari df (degree of freedom) total adalah sebesar 59 (n-1) berarti seluruh data responden yang berjumlah 60 digunakan seluruhnya untuk analisis regresi linier.

Tabel 4 menunjukkan hasil koefisien regresi linier yang akan dibentuk menjadi persamaan. Tabel 5 adalah hasil uji multikoleniaritas dimana bila terjadi multikolinearitas berarti variabel bebas saling berkorelasi (Supriyadi et al. 2017).

Table 5 Uji multikolinearitas

\begin{tabular}{llcc}
\hline \multirow{2}{*}{ Model } & \multicolumn{2}{c}{ Collinearity statistics } \\
\cline { 3 - 4 } & & Tolerance & VIF \\
\hline 1 & (Constant $)$ & & \\
& X13 & 1,000 & 1,000 \\
\hline 2 & $($ Constant $)$ & & \\
& X13 & 0,978 & 1,022 \\
& X19 & 0,978 & 1,022 \\
\hline
\end{tabular}

Hasil uji menunjukkan nilai VIF berada diantara 1-1,5 kurang dari nilai 10 yang menunjukkan tidak terjadi multikolinearitas antara sesama variabel bebas, dengan nilai tolerance diatas dari 0,1 (Supriyadi et al. 2017). Persamaan dibentuk berdasarkan Model-2, dan persamaannya adalah :

$Y=1,183+0,277 X 13+0,262 X 19$

Berdasarkan Persamaan 1 bisa disimpulkan bahwa pengaruh terbesar yang membuat responden merasa bahwa undang - undang jasa konstruksi belum memenuhi kriteria yang dibutuhkan sebagai panduan penyedia dan pengguna jasa konstruksi adalah X13, kemudian X19.

Persamaan yang terbentuk juga bisa digunakan untuk memprediksi pendapat responden terhadap variabel $\mathrm{Y}$ yaitu dengan mengisi nilai 2 variabel tersebut dengan skala likert, lalu hasil tersebut yang didapatkan dalam bentuk ordinal diubah menjadi bentuk interval, dengan contoh sebagai berikut:

1. Misalnya didapatkan hasil kuesioner dengan nilai likert:

a. X13: Setuju, dengan skala ordinal adalah 4 dan skala interval adalah 4,11

b. X19: Sangat Setuju, dengan skala ordinal adalah 5 dan skala interval adalah 5,327. 
2. Masukkan hasil tersebut kedalam persamaan:

$$
\begin{aligned}
Y= & 1,183+0,277 X 13,+0,262 \times 19 \\
Y= & 1,183+0,277(5,327)+ \\
& 0,262(4,11)=3,74
\end{aligned}
$$

Nilai ini bisa dibulatkan menjadi nilai 4 yang menunjukkan hasil dari rumus mendekati dengan nilai 4 dalam nilai skala likert ordinal dan hasil 4,28 dalam nilai interval yang didapatkan dari hasil survei kuesioner dan analisis penelitian. Hasil perhitungan ini berarti menunjukkan bahwa rumus yang didapatkan bisa menghasilkan nilai yang cukup akurat.

\section{Wawancara terstruktur dan validasi pakar}

Berdasarkan hasil analisis terhadap kuesioner yang telah dilakukan maka didapatkan 4 variabel bebas dengan korelasi terbesar terhadap variabel terikat. Variabel tersebut adalah variabel X12, X13, X14, dan X19. Melalui diskusi dengan pakar - pakar melalui wawancara terstruktur maka diperoleh cara pengembangan dan pencegahan sementara dari masalah yang timbul untuk masing-masing variabel yang dipermasalahkan. Pengembangan atau pencegahan yang bisa diambil adalah Penambahan ketetapan yang mengatur kegagalan bangunan dengan menggabungkan tata penulisan dari ketetapan perihal kegagalan bangunan dari UUJK18/1999 dengan UUJK2/2017 sehingga ketetapan jasa konstruksi bisa dibentuk lebih singkat dengan tambahan penjelasan yang lebih mengatur ketetapan lebih dalam.

Dalam perihal penilai ahli maka penilai tersebut selain memiliki pengalaman yang cukup di dalam bidang permasalahan kegagalan bangunan yang ditangani dan perlu memiliki jenjang pendidikan yang sesuai, berarti pengembangan yang bisa diambil untuk undang - undang jasa konstruksi di masa depan adalah di dalam ketetapan undang undang jasa konstruksi dibutuhkan syarat umum yang lebih mendetail dalam pemilihan seorang penilai ahli. Ketetapan yang lebih mengikat mengenai penggunaan dan pemilihan tenaga kerja konstruksi di dalam undang-undang jasa konstruksi seperti pemberian sanksi atau denda perlu diterapkan, ditambah ketetapan mengenai pengawasan dari instansi terkait mengenai pemilihan tenaga kerja konstruksi.

Sebagai pencegahan permasalahan sanksi, para pihak yang terlibat bisa menyelesaikan permasalahan dengan metode penyelesaian sengketa seperti mediasi, arbitrase atau lainnya, atau pembuatan kontrak dengan sanksi tertentu yang disetujui oleh semua pihak, dengan pengembangan yang bisa diambil adalah penggabungan antara ketetapan UUJK18/1999 dengan ketetapan UUJK2/2017 mengenai perihal sanksi dan denda untuk pihak - pihak yang terlibat sehingga bisa membentuk suatu ketetapan yang lebih mendalam, dikarenakan di dalam UUJK18/1999 tidak diatur dengan terlalu dalam mengenai sanksi bagi pihak - pihak tertentu yang terlibat, tetapi dijelaskan mengenai akibat, hukuman, dan denda akibat sanksi, sedangkan UUJK2/2017 diatur dengan dalam mengenai sanksi - sanksi bagi pihak - pihak tertentu yang terlibat tetapi tidak dijelaskan mengenai akibat, hukuman, dan denda akibat sanksi yang dikenakan.

\section{Kesimpulan}

Kesimpulan yang bisa diambil adalah berdasarkan hasil studi literatur, ditemukan perbedaan di antara UUJK18/1999 dengan UUJK2/2017 yang berupa penambahan beberapa hal baru atau pengurangan di dalam UUJK2/2017. Singkatnya, di dalam UUJK18/1999 ditemukan 12 Bab dan 46 Pasal, sedangkan UUJK2/2017 terdapat 14 Bab dan 106 Pasal. Melalui analisis korelasi dari data survei yang didapatkan melalui penelitian survei bermetode kuesioner, maka ada 4 variabel bebas yang memiliki hubungan korelasi paling kuat terhadap variabel terikat dengan variabel X13 adalah variabel bebas dengan korelasi terkuat, yaitu: (a) Variabel X12: ketetapan mengenai kegagalan bangunan tidak dijelaskan dengan baik; (b) variabel X13: Kurangnya ketetapan yang mengatur pemilihan Penilai Ahli; (c) variabel X14: Kurang jelasnya ketetapan yang mengatur standar Tenaga Kerja Konstruksi; (d) variabel X19: kurang jelasnya peraturan mengenai sanksi untuk pihak pihak yang terlibat dalam pekerjaan konstruksi. Berdasarkan hasil analisis regresi didapatkan dua variabel bebas yang terbentuk kedalam rumus, yaitu variabel X13 dan variabel X19 dengan rumus yang didapatkan adalah:

$Y=1,183+0,277 X 13+0,262 X$

Dari hasil analisis regresi dan rumus yang telah terbentuk, berarti variabel bebas X13 adalah variabel bebas yang memiliki pengaruh paling terbesar terhadap hasil variabel terikat (variabel Y), dengan variabel X19 adalah variabel dengan pengaruh terbesar setelah X13 terhadap hasil variabel terikat (variabel Y).

Melalui wawancara terstruktur dan validasi dengan pakar didapatkan pengembangan dan pencegahan yang bisa diambil terhadap variabel X12, X13, $\mathrm{X} 14$, dan X19 yang memiliki korelasi terbesar terhadap variabel terikat (variabel Y). Berdasarkan analisis data maka pengembangan atau pencegahan paling utama yang bisa diambil adalah terhadap variabel X13 dengan nilai korelasi terbesar. 


\section{Saran}

Saran yang bisa diberikan adalah berdasarkan perbandingan yang dilakukan terhadap masing masing undang - undang tentang jasa konstruksi (UUJK) didapatkan penambahan dan pengurangan dari UUJK18/1999 ke UUJK2/2017, melalui hal tersebut bisa dilihat bagian mana saja yang mengalami pengurangan sehingga bisa dipertimbangkan perlu dimasukkan lagi untuk UUJK di masa kedepan atau tidak, dengan penambahan yang telah dilakukan terhadap UUJK bisa direvisi lagi menjadi bentuk yang lebih baik, dan tentunya bisa dilakukan lagi penambahan terhadap UUJK bila ada hal lain yang telah dipertimbangkan.

Dalam menjalankan kegiatan jasa konstruksi perlu berhati - hati dalam menangani variabel - variabel yang disebutkan di atas, yaitu mengenai kegagalan bangunan, penilai ahli, tenaga kerja konstruksi, dan sanksi dalam sengketa jasa konstruksi, dikarenakan berdasarkan analisis yang telah dilakukan, keempat variabel inilah yang menurut responden belum mampu diatur dengan baik di dalam undang- undang tentang jasa konstruksi yang berlaku saat ini.

Undang - undang tentang jasa konstruksi masih bisa dilakukan pengembangan, terutama ketetapan mengenai kegagalan bangunan, penilai ahli, tenaga kerja konstruksi, dan sanksi. Untuk penelitian yang memiliki topik yang serupa dengan penelitian ini, bisa menggunakan metode - metode lain yang tidak digunakan dalam penelitian ini, tergantung jenis data yang dimiliki berupa nominal, ordinal, atau interval. Penelitian di masa depan bisa menggunakan software pengolah data statistik lain selain IBM SPSS Statistics 23.

\section{Ucapan terima kasih}

Ucapan terima kasih diberikan kepada editor dan reviewer yang telah menelaah dan mereview Jurnal "Analisis Undang Undang Tentang Jasa Konstruksi Indonesia Terhadap Pengguna Dan Penyedia Jasa Konstruksi". Penulis juga berterima kasih kepada para responden dan pakar atas kesediaannya dalam membantu penelitian ini terselesaikan, seluruh pihak program Pasca Sarjana Manajemen Konstruksi Universitas Tarumanagara, dan rekanrekan penulis yang terus memberi dukungan.

\section{Daftar Pustaka}

Ariadi, R. (2017). Sandingan Analisis Kegagalan Bangunan (UUJK Nomor 18 Tahun 1999 dan UUJK Nomor 2 Tahun 2017), Thesis, Indonesia: Universitas Tarumanagara.
Chandra, H. (2018). Kedudukan Undang-Undang Nomor 32 Tahun 2002 tentang Penyiaran tanpa Tanda Tangan Presiden. Jurnal PPKn \& Hukum, 13(1).

Endah, R. W. (2011). Uji Validitas dan Reliabilitas Dalam Penelitian Epidemiologi Kedokteran Gigi. Stomatognatic (J.K.G. Unej), 8(1), 27-34.

Ernawijaya, M. (2015). Hubungan antara Partisipasi Anggaran dengan Senjangan Anggaran dalam Menciptakan Akurasi Anggaran pada PT PINAGO Utama Kebun Sereka Kecamatan Babat Toman Kabupaten Musi Banyuasin. Jurnal Akuntansi Politeknik Sekayu (ACSY), 3(1).

Fanani, I., Djati, S., Panja, \& Silvanita, K. (2018). Pengaruh Kepuasan Kerja dan Komitmen Organisasi terhadap Organizational Citizenship Behavior (OCB) (Studi Kasus RSU UKI). Fundamental Management Journal, 1(S)(1).

Ghasemi, A., \& Zahediasl S. (2012). Normality Test for Statistical Analyisis: A Guide for Non Statisticians. International Journal of Endocrinology Metabolism, 10(2).

Hasan, M. T. (2011). Islam dalam Persepktif Socio Cultural, 2005, dalam Prof. Dr. H. Juhaya S. Praja, M. A, Teori Hukum dan Aplikasinya. Bandung: Pustaka Setia.

Haslinda \& Jamaluddin, M. (2016). Pengaruh Perencanaan Anggaran dan Evaluasi Anggaran terhadap Kinerja Organisasi dengan Standar Biaya sebagai Variabel Moderating pada Pemerintah Daerah Kabupaten Wajo. Jurnal Ilmiah Akuntansi Peradaban, 2(1).

Kristanto, A. (2016). Analisis Faktor Penyimpangan pada Kontrak Konstruksi Oleh Pengguna Jasa, Thesis, Indonesia: Universitas Tarumanagara.

Liyanto, S. (2017). Analisis Potensi Masalah yang Menghambat Penerapan Keberlanjutan Konstruksi pada Aspek Kesehatan dan Keselamatan Kerja (UUJK Nomor 2 Tahun 2017), Thesis, Indonesia: Universitas Tarumanagara.

Mahlangu, B. P., \& Kruger, L. P. (2015). The Impact of the Maintenance System: a Case Study of the Petrosa GTL Refinery. South African Journal of Industrial Engineering, 26(3).

Maryuliana, M., Subroto, I. M. I., \& Haviana, S. F. C. (2016). Sistem Informasi Angket Pengukuran Skala Kebutuhan Materi Pembelajaran Tambahan sebagai Pendukung Pengambilan Keputusan di Sekolah Menengah Atas Menggunakan Skala 
Likert. Jurnal Transistor Elektro dan Informatika (TRANSISTOR EI), 1(2), 1-12.

Nugroho, S. B., Nugroho, D., \& Kustanto. (2014). Korelasi Antara Prestasi Akademik Dengan Tingkat Kemampuan TIK Pada Sekolah Dasar Negeri 3 Malangjiwan. Jurnal TIKomSiN, 2(2).

Nurudin, M., Mara, N. M., \& Kusnandar, D. (2014). Ukuran Sampel, dan Distribusi Sampling dari Beberapa Variabel Random Kontinu. Pontianak L Buletin Ilmiah Mat. Stat. dan Terapannya (Bimaster), 3(1).

Pemerintahan Negara Republik Indonesia. (1999). Undang - Undang Jasa Konstruksi Nomor 18 Tahun 1999 tentang Jasa Konstruksi. Retrived April 10 2018, from https://bppk.kemenkeu.go .id/images/peraturan/7.\%20UU18-1999.pdf

Pemerintahan Negara Republik Indonesia. (2011). Undang - Undang Nomor 12 Tahun 2011 tentang Pembentukan Peraturan Perundang - Undangan. Retrived April 10 2018, from https://kelembagaan. ristekdikti .go.id/wp-content/uploads/2016/08/UU12-Tahun-2011.pdf

Pemerintahan Negara Republik Indonesia. (2017). Undang - Undang Jasa Konstruksi Nomor 2 Tahun 2017 tentang Jasa Konstruksi. Retrived April 10 2018, from http://www.lkpp.go.id/v3/files /attachments/5_shOZLkcQtAWWUCHVmDOnNv htzMvlPLyp.pdf

Pratomo, D. S., \& Astuti, E. Z. (2015). Analisis Regresi dan Korelasi antara Pengunjung dan Pembeli terhadap Nominal Pembelian di Indomaret Kedungmundu Semarang dengan Metode Kuadrat Kecil. CyberKU Journal.

Pujilestari, S., Dwidayati, N., \& Sugiman. (2017). Pemilihan Model Regresi Linier Berganda Terbaik pada Kasus Multikolinearitas berdasarkan Metode
Principal Compenent Analysis dan Metode Stepwise. UNNES Journal of Mathematics, 6(1).

Ridha, N. (2017). Proses Penelitian, Masalah, Variabel dan Paradigma Penelitian. Jurnal Hikmah, 14(1).

Ridwan. (2016). Hukum dan Perubahan Sosial: (Perdebatan Dua Kutub antara Hukum sebagai Social Control dan Hukum sebagai Social Engineering). Jurisprudence, 6(2).

Soerjono, S. (1981). Fungsi hukum dan perubahan sosial. Bandung: Alumni.

Supriyadi, E., Mariani, S., \& Sugiman. (2017). Perbandingan Metode Partial Least Square (PLS) dan Principal Component Regression (PCR) Untuk Mengatasi Multikolinearitas pada Model Regresi Linier Berganda. UNNES Journal of Mathematics, 6(2).

Triarman, C., \& Sekarsari, J. (2018). Analisis Faktor Penyebab Keterlambatan Waktu pada Pekerjan Struktur Atas Proyek Konstruksi. Jurnal Penelitian Karya Ilmiah Lembaga Penelitian Universitas Trisakti, 3(2).

Uyanik, G. K., \& Guler, N. (2013, Desember). A Study on Multiple Regression Analysis. Paper Presented at 4th International Conference on New Horizon Education, Sakarya, Turkey.

Widjaja, F. N., \& Sandjaja, S., S. (2013). Uji Validitas dan Reliabilitas Index of Teaching Stress (ITS). Jurnal NOETIC Psychology, 3(2).

Widodo, R. S. (2015). Analisis Pelanggaran Kewajiban Pengguna Jasa berdasarkan Kontrak FIDIC dan AS 4000 - 1997 pada Proyek Gedung Bertingkat Tinggi di Jakarta, Thesis, Indonesia: Universitas Tarumanagara. 